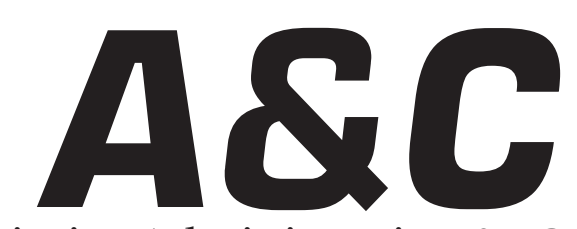

Revista de Direito Administrativo \& Constitucional

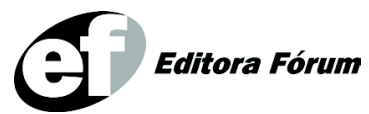

ISSN $1516-3210$ 


\section{A\&C REVISTA DE DIREITO ADMINISTRATIVO E CONSTITUCIONAL}

IPDA

Instituto Paranaense

de Direito Administrativo

Direção Geral

Romeu Felipe Bacellar Filho

Direção Editorial

Paulo Roberto Ferreira Motta

Direção Executiva

Emerson Gabardo

Conselho de Redação

Edgar Chiuratto Guimarães

Adriana da Costa Ricardo Schier

Célio Heitor Guimarães

\section{Conselho Editorial}

Adilson Abreu Dallari

Alice Gonzáles Borges

Carlos Ari Sundfeld

Carlos Ayres Britto

Carlos Delpiazzo

Cármen Lúcia Antunes Rocha

Celso Antônio Bandeira de Mello

Clèmerson Merlin Clève

Clóvis Beznos

Enrique Silva Cimma

Eros Roberto Grau

Fabrício Motta

Guilhermo Andrés Muñoz (in memoriam)

Jaime Rodríguez-Arana Muñoz

Jorge Luís Salomoni

José Carlos Abraão
José Eduardo Martins Cardoso
José Luís Said
José Mario Serrate Paz
Juan Pablo Cajarville Peruffo
Juarez Freitas
Julio Rodolfo Comadira
Luís Enrique Chase Plate
Lúcia Valle Figueiredo
Manoel de Oliveira Franco Sobrinho
(in memoriam)
Marçal Justen Filho
Marcelo Figueiredo
Márcio Cammarosano
Maria Cristina Cesar de Oliveira

Nelson Figueiredo

Odilon Borges Junior

Pascual Caiella

Paulo Eduardo Garrido Modesto

Paulo Henrique Blasi

Paulo Neves de Carvalho (in memoriam)

Paulo Ricardo Schier

Pedro Paulo de Almeida Dutra

Regina Maria Macedo Nery Ferrari

Rogério Gesta Leal

Rolando Pantoja Bauzá

Sérgio Ferraz

Valmir Pontes Filho

Yara Stropa

Weida Zancaner

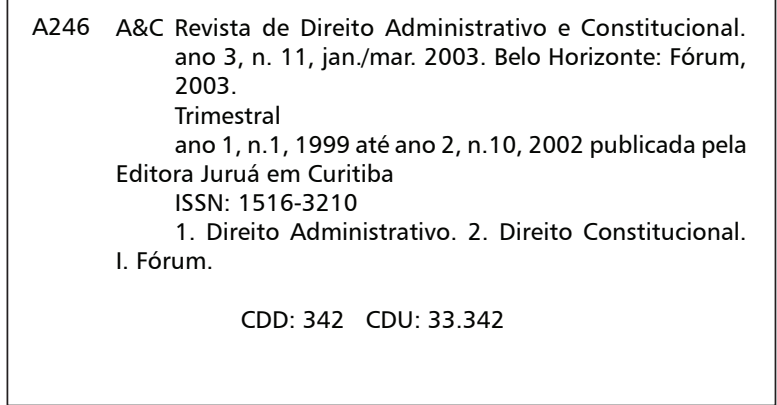

(c) Editora Fórum Ltda. 2006

Todos os direitos reservados. É proibida a reprodução total ou parcial, de qualquer forma ou por qualquer meio eletrônico ou mecânico, inclusive através de processos xerográficos, de fotocópias ou de gravação, sem permissão por escrito do possuidor dos direitos de cópias (Lei $n^{\circ}$ 9.610, de 19.02.1998).

\section{Editora Fórum Ltda}

Av. Afonso Pena, 2770 - 15\%16ªndar - Funcionários

CEP 30130-007 - Belo Horizonte/MG - Brasil

Tel.: 08007043737

Internet: www.editoraforum.com.br

e-mail: editoraforum@editoraforum.com.br
Editor responsável: Luís Cláudio Rodrigues Ferreira Projeto gráfico e diagramação: Luis Alberto Pimenta Revisora: Olga M. A. Sousa

Pesquisa jurídica: Fátima Ribeiro - OAB/MG 74868

Bibliotecária: Alessandra Rodrigues da Silva CRB 2778/MG 6 ${ }^{\text {a Região }}$

Os conceitos e opiniões expressas nos trabalhos assinados são de responsabilidade exclusiva de seus autores.

Impressa no Brasil / Printed in Brazil

Distribuída em todo Território Nacional 


\title{
Os limites das alterações qualitativas nos contratos administrativos
}

Luciano Elias Reis

Advogado, integrante do quadro técnico da Consultoria Zênite. Especialista em Processo Civil e Especializando em Direito Administrativo no Instituto de Direito Romeu Felipe Bacellar

\begin{abstract}
Sumário: Importância do tema - Prerrogativas da administração nos contratos administrativos - Diferenças entre alteração quantitativa e qualitativa - Alterações qualitativas - Limites das alterações qualitativas - Conclusão - Referências

Palavras-chave: Direito público. Contrato administrativo. Alterações qualitativas. Lei de Licitações.
\end{abstract}

\section{Importância do tema}

Preambularmente, estender-se-ão alguns comentários acerca da importância do presente tema. Embora a Lei no 8.666/93 estipule as hipóteses legais para a alteração unilateral contratual, vários aspectos decorrentes desta permanecem questionáveis, dos quais emergem diversos debates doutrinários.

O Tribunal de Contas da União inclina-se para uma determinada vertente, quanto à obediência das alterações qualitativas aos percentuais fixados no $\S 2^{\circ}$ do art. 65 . Todavia em suas decisões também abre margem à ocorrência de hipóteses excepcionalíssimas em que o limite percentual poderia ser extrapolado.

Frente a tais circunstâncias e uma vez que tais situações se deparam quotidianamente nos mais diversos órgãos e entidades da Administração Pública, entende-se oportuno aprofundar diversos aspectos correlacionados ao assunto.

\section{Prerrogativas da administração nos contratos administrativos}

Como se sabe, a Administração Pública tem uma série de prerrogativas e sujeições que lhe são inerentes ante sua posição diferenciada.

Os contratos administrativos, como instituto jurídico firmado pela Administração Pública, recebem tratamento diferenciado aos contratos privados. Enquanto nestes prevalecem, a rigor, em todas as circunstâncias a vontade das partes, naqueles existem situações em que não há necessidade da aquiescência do co-contratante (particular), pois o elemento volitivo da entidade administrativa figura-se como superior à mera deliberação em

A \& C R. de Dir. Administrativo e Constitucional, Belo Horizonte, ano 6, n. 15, p. 109-132, jul./set. 2006 
aceitar ou não. ${ }^{1}$

Pode-se assim dizer que as partes no contrato administrativo não se encontram em par de igualdade. O regime jurídico a que está sujeita a Administração Pública inflige sua conduta diferenciada. Seus privilégios e peculiaridades decorrem do devido respaldo legal, atendendo o princípio da juridicidade. ${ }^{2}$

Já o particular contratado deve respeitar as normas que lhe acometem em virtude do seu regime jurídico, no qual se propugna a consensualidade e a vinculação das obrigações contraídas no ajuste. Todavia, urge mencionar que nem todos os contratos no Direito Privado podem ser vistos como imutáveis. Isto porque se admite em algumas circunstâncias a flexibilização da regra pacta sunt servanta. ${ }^{3}$ Exemplo desta, vislumbra-se nos contratos com cláusulas rebus sic standibus, as quais prevalecem vigentes e aplicáveis para disciplinarem as partes enquanto perdurar o mesmo estado das coisas.

Apesar dessas distinções entre o regime jurídico de Direito Público e de Direito Privado, vale lembrar que o contrato administrativo tem em comum com os contratos em geral outras características, como: a consensualidade entre as partes; a comutatividade; em regra, formalismo; sinalagmaticidade e o caráter intuitu personae. ${ }^{4}$

Celso Antônio Bandeira de Mello $^{5}$ defende que o contrato administrativo não é propriamente um contrato. Deveria ser encarado como um

\footnotetext{
Sobre o contrato administrativo, Antonio A. Queiroz aduz o seu conceito e algumas de suas características: "Contrato administrativo é o firmado entre a Administração Pública e o particular (pessoa física ou jurídica) ou, ainda, com órgãos igualmente de natureza pública, visando a consecução de seus interesses.

(...)

Resumidamente, são características dos contratos administrativos: a- a visualização da Administração Pública, como parte da relação contratual; b- o interesse público que, necessariamente, emerge de todo contrato administrativo; c- a sujeição à forma legal; d- a observância da licitação (salvo exceções expressamente decorrentes da lei); e- aceitação, em bloco, das condições do contrato, às quais o contratado, praticamente, adere". (TELLES, Antonio A. Queiroz. Introdução ao direito administrativo. 2. ed. rev., atual. e amp. São Paulo: R. dos Tribunais, 2000. p. 242-243).

2 Adota-se o princípio da juridicidade ao invés do princípio da legalidade estrita, uma vez que se considera aquele como mais adequado à Administração Pública. Sobre o princípio em comento, Cármen Lúcia Antunes Rocha argumenta o porquê de sua classificação:

"A preferência que se confere à expressão deste princípio da juridicidade, e não apenas ao da legalidade como antes era afirmado, é que, ainda que se entenda esta em sua generalidade (e não na especificidade da lei formal), não se tem a inteireza do Direito e a grandeza da Democracia em seu conteúdo, como se pode e se tem naquele. Se a legalidade continua a participar da juridicidade a que se vincula a Administração Pública - é certo que assim é -, esta vai muito além da legalidade, pois afirma-se em sua autoridade pela legitimidade do seu comportamento, que não se contém apenas na formalidade das normas jurídicas, ainda que consideradas na integralidade do ordenamento de Direito". (ROCHA, Cármen Lúcia Antunes. Princípios constitucionais da Administração Pública. Belo Horizonte: Del Rey, 1994. p. 69-70).

3 Acerca do assunto, vide GOMES, Orlando. Transformações gerais do direito das obrigações. 2. ed. São Paulo: R. dos Tribunais, 1980. p. 95).

4 Hely Lopes Meirelles comenta cada umas dessas características da seguinte forma:

"O contrato administrativo é sempre consensual e, em regra, formal, oneroso, comutativo e realizado intuitu personae. É consensual porque consubstancia um acordo de vontades, e não um ato unilateral e impositivo
} 
ato administrativo. Mesmo assim, pontua duas características marcantes dessa espécie, quais sejam: a consensualidade - em virtude das partes expressarem a sua vontade em ajustar-se - e a autoridade - o que justifica as prerrogativas inerentes à Administração Pública, também denominadas de cláusulas exorbitantes. (MELLO, 2002, p. 551 et seq.).

Contudo, para o presente estudo não aprofundar-se-á sobre o enquadramento e a existência do contrato administrativo ante a teoria geral dos contratos e quiçá sobre o seu rótulo adequado.

Por linhas gerais, verifica-se que nos contratos tipicamente administrativos, ${ }^{6}$ dentre as variadas prerrogativas encartadas como passíveis de concretizarem-se pela Administração Pública, a mais marcante para a sua singularização é a faculdade dela impor modificações unilaterais no ajuste.

Como alinhavado, esse traço é considerado como a marca mais acentuada dos contratos administrativos do ponto de vista para diferenciação com os demais contratos.

Esse poder que lhe é conferido denomina-se de jus variandi ou mutabilidade do contrato administrativo.

A mutabilidade entabula uma cláusula implícita aos termos expressamente convencionados, pois a Administração Pública poderá variar algumas condições a serem realizadas para a devida execução do objeto, o que per si legitima-se pelo adequado atendimento ao interesse público em vista da situação.

A sua prática emoldura um dever-poder que o regime jurídico agasalha para que se execute o contrato celebrado de acordo com o interesse público clamado.

Seguindo esse entendimento, Edmir Netto de Araújo dispõe que: "Mutabilidade do contrato administrativo é, pois, o poder-dever do Estado de alterar uma ou várias de suas cláusulas contratuais por interesse público". (ARAÚJO, 1987, p. 30).

Nos contratos diversos, em regra, prevalece o que fora combinado

da Administração; é formal porque se expressa por escrito e com requisitos especiais; é oneroso porque remunerado na forma convencionada; é comutativo porque estabelece compensações recíprocas e equivalentes para as partes; é intuitu personae porque deve ser executado pelo próprio contratado, vedadas, em princípio, a sua substituição por outrem ou a transferência do ajuste". (MEIRELLES, Hely Lopes. Direito administrativo brasileiro. 23. ed. São Paulo: Malheiros, 1990. p. 189-190).

5 Esta linha advém do escólio do Prof. Oswaldo Aranha Bandeira de Mello (MELLO. Oswaldo Aranha Bandeira de. Princípios gerais de direito administrativo. Rio de Janeiro: Forense, 1969. v. 1, p. 593 et seq.).

6 Tal denominação é descrita para diferenciar dos "contratos privados" da Administração Pública.

Insta relevar que há vozes na boa doutrina pátria as quais negam a existência de contratos privados da Administração Pública. (SUNDFELD, Carlos Ari. Licitação e contrato administrativo. São Paulo: Malheiros, 1994. p. 199-200).

A \& C R. de Dir. Administrativo e Constitucional, Belo Horizonte, ano 6, n. 15, p. 109-132, jul./set. 2006 
pelas partes e as obrigações assumidas vinculam as partes. Já nos contratos administrativos transparece a prerrogativa específica da Administração Pública em alterá-lo sempre que lhe for oportuno e conveniente, desde que atendidas as demais exigências legais. ${ }^{7}$

Sobressai que o regime jurídico aplicável aos contratos administrativos não prevê de forma cega a alteração contratual sem qualquer proteção ao contratado. Senão a Administração Pública não conseguiria quase nunca ou nunca alguém para pactuar. Por isso, a lei estabelece que a modificação não poderá jamais violar alguns direitos do contratado. Dentre estes, figura o equilíbrio econômico-financeiro, com reflexo direto nas cláusulas financeiras convencionadas.

Odete Medauar discorre, acerca do assunto, com a seguinte precisão:

A possibilidade de modificação unilateral não se reveste de caráter absoluto. $\mathrm{O}$ mesmo inciso I do art. 58 menciona, ao final, o respeito aos direitos dos contratados.

Tais direitos apresentam-se sob dois prismas. O primeiro diz respeito ao chamado equilíbrio econômico-financeiro do contrato. O equilíbrio econômico-financeiro significa a proporção entre os encargos do contratado e a sua remuneração, proporção esta fixada no momento da celebração do contrato; diz respeito às chamadas cláusulas contratuais, terminologia redundante, classicamente usada para designar as cláusulas referentes à remuneração do contratado; além dessas, o contrato administrativo é dotado das chamadas cláusulas regulamentares, atinentes às regras de execução. $\mathrm{O}$ direito ao equilíbrio econômico-financeiro assegura ao particular contratado a manutenção daquela proporção durante a vigência do contrato. Se houver aumento dos encargos, a remuneração deverá ser aumentada também. Esse direito vem reconhecido nos seguintes dispositivos da lei acima: $\S 1^{\circ}$ do art. 58 ; $\S 2^{\circ}$ do art. $58 ; \S 6^{\circ}$ do art. 65. (MEDAUAR, 1998, p. 134).

Como se visualiza, o contrato administrativo possibilita à Administração Pública a mudança de cláusulas anteriormente ajustadas.

Eduardo García de Enterría e Tomáz-Ramón Fernandez asseveram

\footnotetext{
Nesse sentido, Marçal Justen Filho também delineia o embate doutrinário e demarca como característica específica ao regime jurídico aplicável ao contrato administrativo a factibilidade de sua alteração. Esse comentário explicita-se com os seguintes dizeres:

"Entre as características do regime jurídico peculiar aos contratos administrativos, talvez a mais acentuada resida na faculdade de sua modificação por ato unilateral da Administração Pública. Toda doutrina reconhece a presença desse traço nos ditos contratos administrativos. Muitos doutrinadores chegam a localizar nesse caráter o ponto diferencial entre contratos administrativos e contratos de direito comum. Segundo essa visão, o contrato administrativo envolveria uma conjugação de cláusulas mutáveis e de cláusulas inalteráveis pela vontade unilateral da Administração Pública - inversamente ao que se passa nos contratos de direito comum, em que todas as cláusulas são vinculantes para ambas as partes. Vai um certo exagero em tais considerações, a meu ver. No entanto é inegável que os contratos administrativos comportam inerentemente uma competência para a Administração Pública, relacionada com a modificação de seu objeto". (JUSTEN FILHO, Marçal. Limites às alterações de contratos administrativos. Revista Zênite de Licitações e Contratos - ILC, Curitiba, n. 42, p. 605, ago. 1997).
} 
que o jus variandi transluz a maior singularidade do contrato administrativo. A conclusão desprende-se da seguinte passagem textual: “O chamado jus variandi ou o poder de modificação unilateral do objeto do contrato é a mais espetacular das singularidades do contrato administrativo enquanto que aponta diretamente a um dos pressupostos básicos do instituto contratual - pacta sunt servanda, contractus lex inter partes". (GARCÍA DE ENTERRÍA; FERNANDEZ, 1990, p. 648).

Vale atentar que a modificação unilateral comentada não se confunde com a alteração advinda de hipóteses decorrentes da teoria da imprevisão, do fato do príncipe ou de qualquer motivo de força maior ou caso fortuito. A causa legítima para a variação unilateral fundamenta-se na adaptação que o interesse público exige em face de fatos supervenientes sucedidos, os quais coagem a Administração Pública a praticar a mutação. ${ }^{8}$ Fala-se em coação para demonstrar a idéia de que a alteração revela-se impreterível para o alcance do interesse público, porque se está diante de um dever-poder e não de um "poder-dever".

Segundo já dito, há algumas cláusulas contratuais que não podem ser alvo de modificação unilateral por parte da Administração sob pena de incorrer em violação de direito adquirido.

Para tanto, enunciar-se-á sobre a classificação das cláusulas do contrato administrativo. ${ }^{9}$ As cláusulas são segmentadas em (i) regulamentares e (ii) econômicas.

As regulamentares disciplinam sobre o objeto do ajuste, a forma como será concretizada a sua execução, quais as sanções administrativas aplicáveis em decorrência da falta contratual, como suceder-se-á o recebimento do objeto, a forma pela qual a fiscalização operar-se-á, etc.. Ou

\footnotetext{
8 "La mutabilidad del contrato importa que si el interés público lo justifica, podría adaptárselo y modificárselo; es su flexibilidad, frente a la rigidez de los contratos privados.

No necesita el Estado invocar la teoría de la imprevisión, el caso fortuito o la fuerza mayor para modificar un contracto de esta naturaleza; esas son causales para modificar el contracto a pedido del concesionario o licenciatario". GORDILLO, Augustín. Derecho administrativo. 8. ed. Buenos Aires: F.D.A., 2003. XI-26.

9 No que concerne à classificação das cláusulas contratuais, Roberto Ribeiro Bazilli comenta que:

"As cláusulas dos contratos administrativos classificam-se em regulamentares e econômicas. As primeiras dispõem sobre o objeto do contrato e sua execução (fiscalização, penalidades, etc.); já, as segundas dizem respeito à equação econômico-financeira do contrato, ou seja, à remuneração decorrente do contrato, na qual está previsto o lucro por parte do contratado.

A alteração unilateral diz respeito sempre a estas cláusulas regulamentares ou de serviços, que, pela própria natureza, são mutáveis, equiparando-se, na lição de Duguit, às leis, que podem ser revogadas ou modificadas no interesse público. Assim, também as cláusulas regulamentares podem e devem ser alterados de maneira a não 'impedir a Administração de acompanhar as inovações tecnológicas, que também atingem as atividades do Poder Público e reclamam a sua adequação às necessidades dos administrados'.

Com relação às cláusulas econômico-financeiras é inadmissível qualquer alteração unilateral do contrato, pois que produziria, fatalmente, o desequilíbrio da equação econômica inicial. Estas somente podem ser alteradas por acordo das partes (art. 65, II, 'd')". (BAZILLI, Roberto Ribeiro. Contratos administrativos. São Paulo: Malheiros, 1996. p. 89-90).
} 
seja, elas regulamentam o desenvolvimento e a execução do pacto firmado, salvo as situações de pagamento. Também há quem as chamem de cláusulas de serviço. Estas poderão ser alvo de alteração unilateral por parte da Administração.

As cláusulas econômicas atinam-se ao equilíbrio econômico-financeiro estabelecido no contrato. Todas as regras referentes à remuneração percebida no ajuste. Estas, a priori, não podem ser modificadas de forma unilateral. Para a alteração de tais resta impreterível o consentimento dos pólos contratantes.

O embasamento para que as cláusulas regulamentares não possam ser imutáveis revela-se estampado na infactibilidade de impedir a Administração de seguir as inovações tecnológicas ou também de adequar o contrato já firmado aos novos anseios. ${ }^{10}$

\section{Diferenças entre alteração quantitativa e qualitativa}

O regime jurídico aplicável aos contratos administrativos ${ }^{11}$ possibilita que o teor destes possa ser alterado pela entidade administrativa contratante a qualquer momento, quando houver algum fato superveniente, o qual não era conhecido à época da contratação ou não se podia mensurar, que clame por este agir da Administração, sob pena de prejuízo ao interesse público primário perseguido na contratação.

Prioristicamente, nota-se que o texto legal expressa alterações qualitativas, quando houver necessidade de adequação do projeto, e quantitativas, quando se fizer necessário o acréscimo ou a diminuição da quantidade do objeto contratado.

As alterações qualitativas têm como cerne a insofismável modificação de especificação/característica do objeto contratado, visto que a sua finalidade poderá restar prejudicada ou não atingida caso não aconteça a devida adequação do projeto. São, de regra, imprevisíveis ou, então, inevitáveis, exigindo, porém, justificativa de ordem técnica que justifique a sua imperiosidade para o alcance do mister pactuado.

Para essa espécie de alteração suceder, alguns pressupostos deverão

\footnotetext{
${ }^{10}$ Nesta diretriz, Hely Lopes Meirelles relatou em sua obra Licitação e contrato administrativo. 10. ed. São Paulo: Malheiros.

“Imobilizar as cláusulas regulamentares, ou de serviço, nos contratos administrativos, importaria em impedir a Administração de acompanhar as inovações tecnológicas, que também atingem as atividades do Poder Público e reclamam sua adequação às necessidades dos administrados". (MEIRELLES, Hely Lopes. Licitação e contrato administrativo. 10. ed. São Paulo: Malheiros. p. 189).

11 Vide art. 58, inc. I, da Lei de Licitações.
}

A \& C R. de Dir. Administrativo e Constitucional, Belo Horizonte, ano 6, n. 15, p. 109-132, jul./set. 2006 
ser observados, a fim de que o procedimento agasalhe-se da adequada legalidade, os quais são:

a) $\quad \mathrm{fat}$ s u p e r ve ni e n t e o u d e conhecimento superveniente, suficiente para ensejá-la;

b) motivo de ordem técnica, devidamente motivado no processo, tornando-se impreterível para tal conclusão que o interesse público da contratação clame esta mudança;

c) mantença do objeto inicialmente convencionado, não podendo de maneira alguma haver a transmutação ou a desnaturação do objeto, sob pena de violação ao preceito constitucional do dever de licitar; ${ }^{12}$

d) respeito aos direitos adquiridos dos licitantes (manutenção do equilíbrio econômico-financeiro).

Esses requisitos revestem-se da devida indispensabilidade para a ocorrência dessa hipótese legal e serão abordados em tópico doravante.

De forma diversa às alterações qualitativas, entabulam-se as modificações de cunho quantitativo, as quais referem-se apenas ao acréscimo ou à supressão da quantidade do objeto. Esta espécie de alteração não modificará as especificações ou critérios contratuais. Inclusive, o texto legal dispõe que sucederão "nas mesmas condições contratuais" ( $\$ 1^{\circ}$ do art. 65 da Lei $n^{\circ} 8.666 / 93$ ) e devem processar-se apenas nos limites permitidos, havendo norma expressa neste sentido ( $\$ 2^{\circ}$ do art. 65 da mencionada lei).

Ademais, é possível afirmar, em razão da prescrição legal acerca do tema, que os acréscimos quantitativos ao contrato estarão limitados aos percentuais indicados na lei, conforme o objeto contratual. Ou seja, a alteração é apenas de quantidade, não podendo haver qualquer modificação no que tange às especificações do objeto.

O cerne do objeto contratado não pode ser alterado e sim acrescido/ suprimido, mediante termo aditivo competente. Por esta razão, não se permite a inclusão, a título de acréscimo/supressão, de objeto não previsto inicialmente.

A modificação cinge-se à dimensão do objeto. ${ }^{13}$ Corresponde dizer

\footnotetext{
${ }^{12}$ A transfiguração ou transmutação do objeto não poderá existir em qualquer alteração unilateral, visto que as exigências qualificadas como técnicas e econômicas são eleitas de acordo com o objeto licitado. Convém lembrar que esta assertiva encontra supedâneo no art. 37, XXI, da Constituição Federal de 1988. As características essenciais do objeto configuram-se como verdadeira barreira à ocorrência de mutação do foco da contratação. Se modificado substancialmente o objeto, estar-se-á diante de uma contratação sem a precedência de prévio procedimento licitatório - situação que é vedada pelo ordenamento jurídico.
} 
que a alteração quantitativa recairá sobre a mensuração do foco contratual. Lembra-se que a supressão ou o acréscimo poderá ensejar a revisão dos valores inicialmente pactuados pela entidade contratante, em virtude da economia de escala (art. $65, \S 6^{\circ}$ ).

Os requisitos obrigatórios para o acontecimento de alteração quantitativa são:

a) $\quad \mathrm{fat}$ o $\mathrm{su} \mathrm{p}$ e rve ni e n t e o u d e conhecimento superveniente, suficiente para ensejá-la;

b) motivo de ordem técnica, devidamente motivado no processo, tornando-se impreterível para a conclusão do interesse público estampado na contratação em lume;

c) respeito aos direitos adquiridos dos licitantes (manutenção do equilíbrio econômico-financeiro e intangibilidade do objeto).

Para finalizar esses brevíssimos comentários, vale frisar que tanto a alteração de ordem quantitativa quanto a qualitativa devem advir de fato superveniente e serão concretizadas por intermédio de justificativa acostada nos autos do processo administrativo, bem como por meio do devido termo aditivo.

\section{Alterações qualitativas}

A alínea "a" do inc. I do art. 65 da Lei de Licitações estatui a hipótese de incidência para a ocorrência de alteração unilateral qualitativa. Esta espécie de modificação contratual é utilizada para os suportes fáticos que reclamem pela mutação do projeto confeccionado ou de suas especificações. A justificativa para esta atitude coaduna-se com a idéia de melhor adequação técnica frente ao interesse público objetivado.

A alteração qualitativa poderá ser visualizada em diversas situações concretas. Não se configura como difícil a incidência de alteração qualitativa.

Luiz Alberto Blachet relata com propriedade alguns casos desse enquadramento legal:

\footnotetext{
${ }^{13}$ Sobre o assunto, Fernando Vernalha Guimarães delineia que:

"Serão consideradas alterações quantitativas para efeitos da Lei no 8.666/1993 aquelas que versem sobre variações na dimensão do objeto. Admite-se que no curso da execução contratual poderá a Administração deparar-se com a necessidade de ampliar ou restringir o objeto do contrato, conforme assim determine o interesse público primário. Envolvem simples variação de quantidade do objeto, atingindo sua dimensão. Não visam a acréscimos e supressões que, ainda que havidos no seio do contrato, sejam produzidos em decorrência de alterações qualitativas; perseguem imediatamente a variação da dimensão do objeto contratual". (GUIMARÃES, Fernando Vernalha. Alteração unilateral do contrato administrativo. São Paulo: Malheiros, 2003. p. 284-285).
} 
(...) constatando a necessidade de construir uma estrada, por exemplo, elabore o projeto de acordo com as condições impostas pela necessidade atual, contrate o particular para executar a obra, e acabe sendo surpreendida, no curso da execução, por acontecimento imprevisível à época da formalização do contrato, o qual exige revisões no projeto sob pena de resultar, o contrato, total ou parcialmente, em inutilidade.

É o que sucede, por exemplo, quando se descobre que o terreno em determinado trecho do trajeto projetado é constituído de turfa ou qualquer outro material que dificulta sensivelmente a construção. Se há possibilidade de alteração do trajeto sem oneração do contratado, esta será a opção juridicamente recomendável. Se é possível o desvio, mas com oneração da execução, o contratado terá direito à revisão dos preços contratados para manutenção do originário equilíbrio econômico-financeiro.

Poderia também ser o caso de alteração do projeto não quanto ao traçado da estrada, mas quanto ao método executivo, como a execução de base mais profunda e sólida, o que, se acarretar maiores custos, também ensejará a revisão para restabelecimento da equação econômico-financeiro.

Necessário alertar que a constituição do terreno em questão obviamente já existia como tal anteriormente à formalização do contrato, mas era de impossível constatação, e devia necessariamente sê-lo porque, se não o fosse, criar-se-ia um impasse: para muitos estudiosos da matéria, a modificação do projeto e conseqüentemente do contrato seria impossível. Porém a coletividade não pode ser penalizada com a construção de uma estrada conforme o projeto originário, mas intransitável, o que onerará os cofres públicos. Assim, se com ou sem a alteração haverá custos com uma utilidade coletiva, o que nos aponta para a revisão do projeto e conseqüente alteração do contrato. (BLANCHET, 1998, p. 188-189).

Para que possa haver o devido silogismo entre o fato concreto e a subsunção da referida norma, tem-se que discorrer sobre os contornos dessa hipótese legal.

No item anterior, mencionaram-se quais eram os pressupostos para a aplicação do art. 65, inc. I, alínea “a”, da Lei de Licitações e agora expender-se-á acerca de cada um destes.

\section{a) Fato superveniente ou de conhecimento superveniente}

Concluída a licitação e celebrada a contratação, o seu objeto somente poderá ser alterado se for verificada a ocasião de um fato superveniente ou, ainda, que o fato já ocorrera em momento anterior à contratação, no entanto a entidade administrativa não tinha conhecimento.

Esse termo condicional para a aplicação dessa hipótese legal baseiase na impossibilidade de modificação contratual por qualquer motivo.

Senão, por exemplo, a negligência da Administração contratante 
em prever as especificações do projeto para a persecução do objeto estipulado ocasionaria que um ajuste para a execução de uma obra de engenharia cujo preço estabelecido era de $\mathrm{R} \$ 2.000 .000,00$ se convertesse em $\mathrm{R} \$ 2.400 .000,00$, uma vez que fora descoberto pela análise de documentos acerca do subsolo, por meio do acervo da Prefeitura, de que há a existência de canalização em tal região, por onde passa gás natural. Nessa situação, a contratante não se preocupou em descrever e planejar o objeto com a maior precisão possível. Esses cuidados são imanentes à atividade administrativa. Por isso, não se pode conceber como justificativa de fato superveniente a falta de planejamento ou a ausência de cautelas possíveis, salvo exceções adequadamente comprovadas.

Quando se fala acerca de conhecimento posterior à celebração do ajuste, deve-se ter em mente o mesmo raciocínio acima esposado. A ausência de cognição do fato somente impera se a Administração não tiver condições de cientificar-se da determinada circunstância no instante em que contratou.

Essas precauções mostram-se indispensáveis, pois, do contrário, aventar-se-ia que a licitação para mencionado objeto seria somente uma forma de contratar um outro objeto, visto que as alterações transmutariam a sua essencialidade. Tal ato acarretaria a burla do dever de licitar, prática vedada pelo ordenamento jurídico.

\section{b) Motivação}

De acordo com o princípio da motivação, todos os atos administrativos deverão ser justificados, sob pena de ilegalidade. Esta norma advém dos princípios republicanos e do Estado Democrático de Direito.

A autoridade administrativa necessita estampar os porquês que acarretaram o seu agir em determinada direção. Nas alterações unilaterais vige esta regra também.

No livro, que contém orientações básicas para o procedimento licitatório e de contratações administrativas e que o Tribunal de Contas da União publicou, há a prescrição neste norte para a atitude da Administração, senão a validade do ato administrativo estará eivada de vício. Segue o predito trecho: "Para que as modificações sejam consideradas válidas, devem ser justificadas por escrito e previamente autorizadas pela autoridade competente para celebrar o contrato". ${ }^{14}$

A \& C R. de Dir. Administrativo e Constitucional, Belo Horizonte, ano 6, n. 15, p. 109-132, jul./set. 2006 
A justificativa deverá ser pautada nos elementos fáticos, técnicos e jurídicos que conduziram para tal conduta. ${ }^{15}$

Recentemente, o Colendo Superior Tribunal de Justiça descreveu em um julgado a imprescindibilidade de os atos administrativos, inclusive os discricionários, vergarem-se ao princípio da motivação. Colacionase a ementa do citado acórdão proferido pelo eminente Ministro Paulo Medina:

\section{RECURSO ESPECIAL - MANDADO DE SEGURANÇA - TRANSFERÊNCIA DE SERVIDOR PÚBLICO - ATO DISCRICIONÁRIO - NECESSIDADE DE MOTIVAÇÃO - RECURSO PROVIDO.}

1. Independentemente da alegação que se faz acerca de que a transferência do servidor público para localidade mais afastada teve cunho de perseguição, o cerne da questão a ser apreciada nos autos diz respeito ao fato de o ato ter sido praticado sem a devida motivação.

2. Consoante a jurisprudência de vanguarda e a doutrina, praticamente, uníssona, nesse sentido, todos os atos administrativos, mormente os classificados como discricionários, dependem de motivação, como requisito indispensável de validade.

3. O Recorrente não só possui direito líquido e certo de saber o porquê da sua transferência "ex officio", para outra localidade, como a motivação, neste caso, também é matéria de ordem pública, relacionada à própria submissão a controle do ato administrativo pelo Poder Judiciário.

4. Recurso provido. (BRASIL. Superior Tribunal de Justiça. Recurso em Mandado de Segurança no 2002/0143588/5. Órgão julgador: $6^{\text {a }}$ Turma. Relator: Min. Paulo Medina. Brasília, 19 abr. 2005. DJ, 16 maio 2005).

Salienta-se, ainda, que para a tomada de decisão administrativa a fim de alterar unilateralmente o contrato administrativo, a entidade contratante deverá consubstanciar o seu ato conforme o devido processo legal. Isto significa a imperiosidade de motivação robusta.

Não basta somente a fundamentação de que tal ato decorre para o devido atendimento do interesse público. O simples vernáculo interesse público não é supedâneo para todas as condutas administrativas. ${ }^{16}$

O agente público deverá transluzir, por intermédio da narração dos fatos ocorridos, a correlação lógica que impõe a modificação contratual para a persecução do interesse público. Não está a defender a descrição de

\footnotetext{
${ }^{14}$ BRASIL. Tribunal de Contas da União. Licitações e contratos: orientações básicas/Tribunal de Contas da União. 3. ed. Brasília: TCU, Secretaria de Controle Interno, 2006. p. 350.

${ }^{15} \mathrm{Na}$ mesma diretriz, Luiz Carlos Alcoforado compreende. (ALCOFORADO, Luiz Carlos. Licitação e contrato administrativo: comentário à lei n 8.666, de 21 de junho de 1993. Brasília: Brasília Jurídica, 1996. p. 317).
} 
no mínimo três ou dez páginas, para que seja suprida a justificativa, por exemplo. A motivação estará satisfeita pela devida descrição expressada nos termos expostos nos autos do processo administrativo, a qual provou a necessidade da mencionada conduta. ${ }^{17}$

No tocante especificamente à motivação técnica para as alterações qualitativas, esta deverá centrar-se na causa da modificação da qualidade do objeto.

A atitude de mudar o projeto inicialmente estabelecido ou as suas especificidades embasar-se-ão com fulcro no escopo a ser alcançado com a execução do objeto. O motivo poderá evidenciar-se pela economia de tempo e custos ou ainda pela própria imperiosidade para o atingimento do objeto.

Exemplificando, um contrato de construção de um trecho de estrada de 30 quilômetros. A alteração de um traçado da respectiva estrada, que fora projetada para seguir uma determinada diretriz, pode ter como causa a imperiosidade de implodir um espaço que possui um subsolo rochoso. Para a passagem do trecho de estrada nesta região deverá haver a implosão para a desobstrução do terreno rochoso encontrado no subsolo. Esta informação não se sabia quando da confecção do contrato, porquanto os estudos do solo da região não previam tal composição. Na situação também não se possibilita a mudança de trajeto, sob pena de não atingir o interesse público e/ou a segurança do objeto restar comprometida - por exemplo, segurança da obra, pois curvas muito acentuadas retirariam a devida força gravitacional centrípeta. Então, nesta situação, a alteração qualitativa do objeto, apesar da respectiva majoração dos custos e de tempo, se demonstra indispensável para a persecução do interesse público.

Dessa forma, explana-se pela possibilidade de que a alteração qualitativa se revele pertinente a uma dada situação fática com o encarecimento dos custos e do tempo. Nem sempre a mudança ora tratada ocasionará a economia nos dispêndios de recursos públicos e de tempo para a execução

\footnotetext{
${ }^{16}$ A mesma idéia é compartilhada pelo jurista Mauro Roberto Gomes de Mattos. (MATTOS, Mauro Roberto Gomes de. O contrato administrativo. Rio de Janeiro: América Jurídica, 2001. p. 80).

${ }^{17}$ A título complementar, salienta-se que a Corte de Cassação, no ordenamento italiano, também afastou a tese de integral poder discricionário de modificação unilateral. Resta forçosa a motivação. Acerca deste comentário, Odete Medauar relata que:

"No ordenamento italiano, a Corte de Cassação afastou a tese do poder discricionário de modificação unilateral do contrato, como poder geral independente de previsão legal explícita; afirmou que, salvo a rescisão por interesse público, a relação contratual é regida por cânones paritários. Como se viu, no ordenamento brasileiro a prerrogativa é prevista, circunscrita a limites e ao respeito a direitos dos contratados". (MEDAUAR, Odete. Direito administrativo moderno. 4. ed. São Paulo: R. dos Tribunais, 2000. p. 254).
} 
do objeto.

O limite para o encarecimento do ajuste em virtude de uma alteração qualitativa cinge-se ao cálculo de quanto oneraria à Administração a imposição da rescisão contratual e a deflagração de novo certame para o objeto de acordo com o projeto e as especificações necessárias. ${ }^{18}$

Nessa esteira, o Tribunal de Contas da União prolatou a Decisão no 215/1999 - Plenário:

As alterações qualitativas, (...) "visam apenas à consecução ótima do objeto mediato, que se mantém inalterado em sua natureza e dimensão, por meio do aumento ou supressão do objeto imediato, utilizando-se de obras extras, complementares ou novas em relação às já contratadas, e também requerem, via de regra, mudanças no valor original do contrato".

(...)

Considerados tais balisadores como limites gerais às alterações qualitativas, eles têm como conseqüência a restrição das modificações qualitativas, além dos limites legais estabelecidos, apenas à hipótese de ocorrência cumulativa dos seguintes pressupostos: a) não acarretar para a Administração encargos contratuais superiores aos oriundos de uma eventual rescisão contratual por razões de interesse público acrescidos aos custos da elaboração de um novo procedimento licitatório; e b) não possibilitar a inexecução contratual, à vista do nível de capacidade técnica e econômico-financeira do contratado.

No mesmo sentido, há outras decisões do Tribunal de Contas da União, conforme se constata nas Decisões no 350/2002 (Rel. Augusto Sherman Cavalcanti), no 379/1999 (Rel. Humberto Souto) e no 552/2000 (Rel. Walton Alencar).

Da mesma maneira, na doutrina, Jessé Torres Pereira Júnior sustenta que:

No primeiro caso (inciso I, alínea "a"), a autorização para alterar o contrato terá de atender as duas condições cumulativas:

(a) refletir, tão-só refletir, enfatize-se, a necessidade, que se comprovou tecnicamente em processo administrativo, de modificar o projeto ou as especificações, ou seja, modificação que afeta a qualidade do objeto contratado (por exemplo,

\footnotetext{
${ }^{18}$ Adilson Abreu Dallari evidencia o princípio da economicidade ante as alterações unilaterais, ao aduzir que:

"Uma das finalidades legais certamente sempre será a execução do objeto contratado com a melhor relação custo-benefício, sempre será a aplicação ótima dos recursos públicos, o que pode ser traduzido como a concretização, em cada caso específico, do princípio constitucional da economicidade". (DALLARI, Adilson Abreu. Alterações dos contratos administrativos - economicidade, razoabilidade e eficiência. In: BACELLAR FILHO, Romeu Felipe. (Coord.). Direito administrativo contemporâneo: estudos em memória do professor Manoel de Oliveira Franco. Belo Horizonte: Fórum, 2004. p. 23).
}

A \& C R. de Dir. Administrativo e Constitucional, Belo Horizonte, ano 6, n. 15, p. 109-132, jul./set. 2006 
verifica a Administração, em execução a obra, que um traçado definido no projeto deve ser substituído por outro, com economia de tempo e custos);

(b) a mudança de projeto ou de especificações é necessária para melhor ajustar a prestação contratada aos objetivos que a Administração tem em mira com a execução do contrato (no mesmo exemplo anterior, a substituição do traçado não pode ser devida a um preciosismo técnico, mas importa ao cumprimento da finalidade da obra, que resultaria comprometido sem a modificação). (PEREIRA JÚNIOR, 2003, p. 650).

Assim, pode-se deduzir que a alteração qualitativa somente se consubstancia com a devida justificativa acostada ao processo administrativo e que toda modificação do projeto original ou de suas especificidades suceder-se-á com motivação técnica, sob pena de ilegalidade.

\section{c) Transmutação do objeto inicialmente pactuado}

As alterações qualitativas não poderão ocasionar a transfiguração ou a transmutação do objeto inicialmente convencionado. O limite da transformação do objeto para a persecução do objeto circunscreve-se à essência dele.

É impreterível afirmar que a intangibilidade do objeto deve ser preservada. Não se pode admitir que a alteração qualitativa mascare a existência da violação ao princípio do dever de licitar.

A mudança no projeto e/ou nas suas especificações deve acontecer sem o acréscimo de características ou peculiaridades previsíveis. Do contrário, não haveria o enquadramento de sucessão superveniente ou de cognição posterior à sua celebração. ${ }^{19}$

Inclusive, Petrônio Braz diz que a alteração qualitativa pode configurar-se como um meio de desvio de poder por parte do agente administrativo competente para prejudicar o particular contratado. Colacionam-se os seus comentários:

As modificações do projeto ou das especificações, porém, pelas relações que assentam com o valor do contrato, não podem ser radicais de modo a dar nova feição à obra ou ao serviço, burlando o processo de licitação.

\footnotetext{
${ }^{19}$ Seguindo essa idéia, assaz as palavras de Maria Luiza Machado Granziera:

"No que se refere ao primeiro item - modificação do projeto - cumpre esclarecer que tal modificação não pode descaracterizar a natureza do objeto do contrato, para que não seja ferido o princípio da obrigatoriedade da licitação nem o princípio da competitividade e igualdade entre os licitantes. De fato, o objeto do contrato, que foi adjudicado ao licitante, como ato final de um processo de licitação, não
} 
As modificações não podem configurar atos de desvio de poder, objetivando uma eventual ação punitiva contra o licitante vencedor do certame licitatório, de tal modo que venham a impossibilitar, por parte do contratado, o cumprimento da obrigação. (BRAZ, 1995, p. 177).

Marcos Juruena Vilella Souto defende que o ideal seria que a alteração fosse realizada antes da execução do objeto por parte do contratado, a fim de se obter o grau máximo de aproveitamento do objeto, bem como de minorar desperdícios de tempo e de recursos públicos. Defende também que a eficiência técnica do executante deve ser aferida, sob pena de ofensa aos princípios da moralidade e da eficiência. ${ }^{20}$

Destarte, cumpre à Administração no momento de decisão para a aplicação do art. 65, inc. I, alínea “a”, agir com enorme presteza e respeito aos princípios do regime jurídico do Direito Público. Os princípios da razoabilidade, da proporcionalidade e da finalidade pública guarnecerão este ato administrativo. Caso um desses vetores esteja ausente frente ao caso concreto, ventila-se a ilegalidade. Para tal, fica ao alvedrio da fiscalização e do controle o seu apontamento e a cominação de suas conseqüências legais.

\section{d) Mantença dos direitos adquiridos}

A conservação dos direitos adquiridos é a base para que as cláusulas econômico-financeiras não sofram qualquer tipo de mudança de forma unilateral. O direito adquirido tem respaldo constitucional. $\mathrm{O}$ art. $5^{\mathrm{o}}$, inc. XXXVI, da Constituição da República prescreve que "a lei não prejudicará o direito adquirido, ato jurídico perfeito e a coisa julgada”.

pode sofrer uma alteração substancial, pois se houver a sua descaracterização, configura-se a inobservância dos princípios de direito que asseguram a igualdade e a competitividade entre os licitantes, além da obrigatoriedade da licitação". (GRANZIERA, Maria Luíza Machado. Execução, alteração e rescisão dos contratos administrativos. In: MEDAUAR, Odete (Org.). Licitações \& contratos administrativos: coletânea de estudos. São Paulo: NDJ, 1998. p. 159).

20 "O que não cabe é a descaracterização do objeto inicial, vedada expressamente pelo Estatuto; o permissivo da alteração é a modificação técnica no mesmo objeto, que, se levar à alteração dos encargos do contratado, motivará a alteração de preço (o que deve ter amparo no orçamento, limitador da discricionariedade administrativa).

O ideal era que essas alterações fossem feitas antes do início da execução do projeto, viabilizando uma etapa intermediária entre o projeto básico e o seu detalhamento, com vistas à otimização do projeto, reduzindo custos e melhorando desempenho.

Por fim, a técnica, tanto a original, quanto a que vier alterá-la, deve observar certificação de sistemas de qualidade de acordo com normas tecnicamente aceitas. Vale esclarecer que a alteração qualitativa só é válida se do contratado foi exigida habilitação técnica para tanto na licitação. Do contrário, ainda que o contratado aceite, viola-se o princípio da moralidade e o dever de eficiência técnica". (SOUTO, Marcos Jurena Villela. Direito administrativo contratual. Rio de Janeiro: Lumens Juris, 2004. p. 409). 
Assim, a partir do momento em que o contrato administrativo estabelece as obrigações das partes contratantes e os deveres respectivamente, as cláusulas econômico-financeiras entabulam-se como direito adquirido do contratado.

Não se pode aventar que haja a mutação unilateral das cláusulas econômico-financeiras, sem a devida anuência das partes. Isto feriria a cláusula firmada pelo contratado, o qual em virtude dela faz todo um planejamento em sua estrutura empresarial.

Como já dito em oportunidade anterior, se as cláusulas econômicofinanceiras pudessem de forma unilateral ser alteradas pela Administração, bem provável o rol de particulares com interesse em celebrar contratos administrativos despencaria e quem sabe até nem existiria.

Além daquele dispositivo constitucional, vale recordar o inc. XXI do art. 37 da Constituição da República, o qual menciona que a contratação efetivar-se-á desde que "mantidas as condições efetivas da proposta, nos termos da lei”. Não se assente a factibilidade de ocorrência de alteração contratual de forma unilateral que desestruturasse as cláusulas econômico-financeiras ajustadas, visto que não haveria a mantença das condições efetivas de proposta.

A Lei de Licitações também protege essa garantia dos contratados face o teor dos dispositivos insculpidos nos $\S \S 1^{\circ}$ e $2^{\circ}$ do art. 58 e no $\S 6^{\circ}$ do art. 65 .

Sob a intelecção de tais preceitos normativos, a Administração quando alterar os ajustes de forma unilateral tem o dever de realinhar o equilíbrio financeiro inicialmente pactuado, sob pena de enriquecimento indevido. ${ }^{21}$

Hely Lopes Meirelles dispõe de forma singular sobre o assunto:

O equilíbrio financeiro, ou equilíbrio econômico, ou equação econômica, ou, ainda, equação financeira, do contrato administrativo é a relação estabelecida inicialmente pelas partes entre os encargos do contrato e a retribuição da Administração para a justa remuneração do objeto do ajuste. Essa relação encargo-remuneração deve ser mantida durante toda a execução do contrato, a

\footnotetext{
${ }^{21}$ Nessa vertente, José Cretella Júnior discorre que:

"A Administração tem o poder-dever de tomar providências imediatas para, por aditamento, restabelecer o equilíbrio econômico-financeiro inicial do contrato, sempre que ocorrer alteração do ajuste, que aumente os encargos do interessado licitante. Este princípio já está firmado, de modo geral, nesta lei, quando o legislador, tratando das Disposições Preliminares dos Contratos, diz que 'as cláusulas econômicofinanceiras do contrato administrativo não poderão ser alteradas sem prévia concordância do contratado' e que, se forem, 'deverão ser revistas para que se mantenha o equilíbrio contratual'". (CRETELLA JÚNIOR, José. Das licitações públicas. 17. ed. Rio de Janeiro: Forense, 2001. p. 360).
} 
fim de que o contrato não venha a sofrer indevida redução nos lucros normais do empreendimento. Assim, ao usar do seu direito de alterar unilateralmente as cláusulas regulamentares do contrato administrativo, a Administração não pode violar o direito do contratado de ver mantida a equação financeira originariamente estabelecida, cabendo-lhe operar os necessários reajustes econômicos para o restabelecimento do equilíbrio financeiro.

Trata-se de doutrina universalmente consagrada, hoje extensiva a todos os contratos administrativos (arts. 57, $\S 1^{\circ}, 58, \mathrm{I}, \S \S 1^{\circ}$ e $2^{\circ}$, e $65, \mathrm{II}$, “d”, e $\S 6^{\circ}$ ). (MEIRELLES, 1990, p. 192-193).

Logo, caso a alteração unilateral imposta pela Administração Pública acarrete alguma conseqüência indireta que interfira na balança econômico-financeira do contrato, deverá haver a imediata restauração da equação econômico-financeira, a fim de que o contratado não sofra algum prejuízo. ${ }^{22}$

Tal posicionamento é pacífico na doutrina pátria e na jurisprudência. Como parâmetro, traz-se uma decisão do Colendo Superior Tribunal de Justiça:

AGRAVO REGIMENTAL - GRATUIDADE DE TRANSPORTE TERRESTRE INTERESTADUAL AO IDOSO - SUSPENSÃO SEGURANÇA - INDEFERIMENTO - MANUTENÇÃO DO EQUILÍBRIO ECONÔMICO-FINANCEIRO DO CONTRATO - LESÃO À ORDEM PÚBLICA NÃO CONFIGURADA.

1. Não se examina em pedido de suspensão lesão à ordem jurídica, cuja análise fica resguardada às vias recursais ordinárias. 2. Ao estabelecer um serviço de transporte de natureza assistencial em favor dos idosos de baixa renda o legislador exigiu, como condição de eficácia do dispositivo, a edição de legislação específica para regulamentar sua execução na integralidade. Diante da inexistência de legislação específica não há que se falar em eficácia do dispositivo legal. 3. O serviço de transporte coletivo rodoviário se realiza por ações de empresas mediante contratos de concessão, permissão ou autorização firmados com o Poder Público. São portanto contratos administrativos nos quais, desde a celebração, deve estar prevista a forma de ressarcimento, pelo Estado, das despesas da empresa na execução do serviço público. 4. Mesmo nos contratos administrativos, ao poder de alteração unilateral do Poder Público contrapõe-se o direito que tem o particular de ver mantido o equilíbrio econômico-financeiro do contrato, considerando-se o encargo assumido e a contraprestação pecuniária garantida pela administração. 5. A Constituição Federal exige que nenhum benefício ou serviço

\footnotetext{
22 Caio Tácito ampara essa assertiva com o seguinte teor:

"Em correspondência a este poder unilateral da Administração será assegurado ao outro contratante o chamado direito ao equilíbrio econômico-financeiro do contrato, de modo a que se torne estável a equivalência entre as obrigações de dar, ou de fazer, de um agente e a obrigação de pagar do outro ator da relação bilateral.

Cuida-se, em suma, de preservar, no contrato revisto, sua natureza comutativa (equivalência intrínseca entre as obrigações) e sinalagmática (reciprocidade das obrigações)". (TÁCITO, Caio. Temas de direito público. Rio de Janeiro: Renovar, 1997. 2. v., p. 1400-1401)
}

A \& C R. de Dir. Administrativo e Constitucional, Belo Horizonte, ano 6, n. 15, p. 109-132, jul./set. 2006 
da seguridade social seja criado, majorado ou estendido sem a correspondente fonte de custeio. 6. Por tratar-se a suspensão de contracautela vinculada aos pressupostos de plausibilidade jurídica do pedido e do perigo da demora, não há prejulgamento do mérito da controvérsia quando no pedido de suspensão exerce o Presidente um Juízo mínimo de deliberação indispensável à aferição de existência ou não de fumus boni iuris. 7. Não havendo lesão a quaisquer dos bens jurídicos tutelados pela norma de regência, é de ser negada a suspensão requerida. 8. Agravo não provido. (Grifamos.) (BRASIL. Superior Tribunal de Justiça. Agravo Regimental na Suspensão de Segurança no 2004/0119581-4. Relator: Min. Edson Vidigal. Órgão julgador: Corte Especial. Brasília, 25 out. 2004. DJ, 06 dez. 2004).

Para que haja a devida mantença dos direitos adquiridos do contratado, além da adequação das cláusulas econômico-financeiras, faz-se impreterível que a Administração, se demonstrada a imprescindibilidade, prorrogue o prazo para a execução do objeto.

A alteração qualitativa inserta no ajuste poderá majorar o tempo para a desenvoltura da execução do objeto, com isso a não modificação no período de vigência contratual resultará na infactibilidade de o contratado cumprir os prazos iniciais pactuados.

A realidade das obrigações transforma-se em algumas alterações qualitativas e, ocorrendo assim, impera à Administração que reveja os prazos que foram estipulados inicialmente. Logo, os prazos deverão ser dilatados ou encurtados dependendo do caso concreto. Esta idéia encontra respaldo no art. 57, $\S 1^{\circ}$, inc. I, da Lei $\mathrm{n}^{\circ}$ 8.666/93.

Marçal Justen Filho concorda com a necessidade de que o cronograma preambularmente estatuído para a execução do objeto seja revisto, de acordo com os seus reflexos perante o suporte fático. ${ }^{23}$

Por conseguinte, a entidade administrativa contratante deverá perquirir a alteração unilateral qualitativa inculcada ao contratado e coadunar tal imposição com as obrigações convencionadas inicialmente, principalmente no que se correlaciona às cláusulas econômico-financeiras e ao prazo de execução.

\section{e) Ciência do contratado}

\footnotetext{
${ }^{23} \mathrm{O}$ autor discorre que:

"Uma das competências anômalas da Administração é a de alterar, unilateralmente, as cláusulas do contrato administrativo. Se exercitar tal faculdade, a Administração pode provocar alteração nos cronogramas de execução das prestações.

As previsões dos incs. I, III e IV do art. 57, $\$ 1^{\circ}$, podem ser reconduzidas a essa hipótese. Em todas essas situações, a Administração exercita faculdade jurídica a ela reconhecida de modificar condições originais
} 
Muito se discute acerca da inevitabilidade de que o contratado seja notificado previamente para conhecimento da pretensão da Administração Pública em alterar o contrato administrativo.

O texto legal não determina expressamente que se deverá cientificar e abrir espaço para que o contratado se manifeste acerca da intenção da Administração em agir desse modo.

Esse requisito somente se transcreve como forma de atentar aos operadores do contrato administrativo para que reflitam acerca desse. Não se esmiuçará e quiçá se chegará a uma conclusão definitiva.

Vera Lúcia Machado D’Avila assinala que a entidade administrativa contratante não está obrigada por ato normativo a informar ao contratado e conceder lapso temporal para que se manifeste (favorável ou contrária à modificação). Entretanto se recomenda tal conduta. Nestes termos escreveu: “(...) a Administração, ao alterar unilateralmente os contratos administrativos, não está obrigada a notificar previamente o contratado, com vistas a estabelecer o contraditório. Todavia, seria conveniente e aconselhável fazê-lo, em razão do princípio da transparência dos atos administrativos." (SANTOS, 2001, p. 262).

Já Ricardo Alexandre Sampaio dedicou um artigo doutrinário para esse tópico, o qual fora veiculado na Revista Zênite de Licitações e Contratos, e chegou à seguinte conclusão:

Em síntese, com pauta nos valores constitucionais do devido processo legal, do contraditório, do dever dos atos administrativos serem motivados e da própria boa-fé contratual que se espera em especial da Administração Pública, conclui-se pela necessidade das alterações unilaterais dos contratos administrativos serem precedidas de momento em que se permita ao contratado contraditar a pretensão do Poder Público contratante, bem como demonstrar o impacto que essas modificações surtirão sobre a equação econômico-financeira, participando assim de maneira ativa das decisões administrativas. Entende-se que assim a Administração Pública estará adotando postura mais condizente com os princípios democrático e republicano que devem orientar o exercício da função pública. (SAMPAIO, 2004, p. 1162).

Consoante às posições supra tracejadas, deduz-se que o tema é bastante polêmico e não se pretende verticalizá-lo neste trabalho, mas

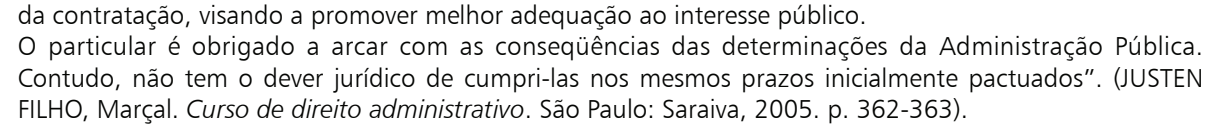

O particular é obrigado a arcar com as conseqüências das determinações da Administração Pública. Contudo, não tem o dever jurídico de cumpri-las nos mesmos prazos inicialmente pactuados". (JUSTEN FILHO, Marçal. Curso de direito administrativo. São Paulo: Saraiva, 2005. p. 362-363). 
tão-somente abordar a sua existência e contrariedade.

\section{Limites das alterações qualitativas}

Este tópico versará sobre o foco do presente trabalho, o qual se refere à existência de limites percentuais fixados de acordo com o valor inicial atualizado do ajuste para a incidência das alterações qualitativas.

$A b$ initio, enuncia que a doutrina diverge no tocante a sua prática.

De um lado se encontram os defensores de que todas as alterações unilaterais adstringem-se ao limite percentual declinado no $\S 1^{\circ}$ do art. 65 da Lei de Licitações. Esta idéia decorre da redação legal do art. $65, \S 2^{\circ}$, que dispõe que "nenhum acréscimo ou supressão poderá exceder os limites estabelecidos no parágrafo anterior".

Já o parágrafo anterior - art. $65, \S 1^{\circ}$ - certifica que o "contratado fica obrigado a aceitar, nas mesmas condições contratuais, os acréscimos ou supressões que se fizerem nas obras, serviços ou compras, até $25 \%$ do valor inicial atualizado do contrato, e, no caso particular de reforma de edifício ou de equipamento, até o limite de $50 \%$ para os seus acréscimos".

Para estes os preceptivos legais ora narrados propendem ao entendimento de que tanto as alterações qualitativas quanto as quantitativas não poderão transcender aos preditos percentuais.

Um dos doutrinadores que escoram essa posição é Marcos Jurena Villela Souto que observa: "O que cabe frisar é que a alteração - seja quantitativa, seja qualitativa - limita-se ao percentual previsto na Lei de Contratações Administrativas". (SOUTO, 2004, p. 409).

No mesmo sentido, compreende Roberto Ribeiro Bazilli (1996, p. 93-94).

Doutra via, existem os que sustentam a idéia de que os percentuais mencionados manuseiam somente as alterações quantitativas. A modificação de índole qualitativa não estaria circunscrita por essas percentagens.

A alteração qualitativa, desde que respeitadas as suas exigências vestibulares, poderá ultrapassar os percentuais. A demonstração de que o projeto e/ ou as suas especificidades merecem ser transformados e a transcendência dos percentuais justificam-se pelos princípios que norteiam o regime jurídico de Direito Público. Deve ser vista esta prática com a máxima cautela pela Administração. A motivação propugnada deverá explicitar a situação de necessidade.

Os princípios da razoabilidade, proporcionalidade, economicidade 
e da finalidade pública consolidarão a prática da Administração em superar os precitados limites percentuais.

Essa linha ampara-se pela percepção de Adilson Abreu Dallari, o qual declara que:

Em resumo: não há limite de valor para alterações qualitativas, destinadas à melhor adequação do objeto do contrato aos seus objetivos. Limites existem, mas não são automáticos ou previamente determinados de maneira genérica. Tais limites terão que ser aferidos em cada caso concreto.

(...)

Em cada obra será necessário examinar as circunstâncias que ensejaram a necessidade da alteração do objeto e a verossimilhança do eventual acréscimo de valor. (...) Nestas verificações terão que ser aplicados critérios de economicidade, de razoabilidade e de eficiência, para se saber se efetivamente existirão ganhos de produtividade, se haverá uma melhoria na relação custo-benefício, se a alteração pretendida proporciona maior rapidez na execução do objeto, se existem ou não ganhos urbanísticos e ambientais e se, ao final, o impacto social será ou não vantajoso. (DALLARI, 2004, p. 26).

Na mesma diretriz, Celso Antônio Bandeira de Mello, ${ }^{24}$ Antônio Carlos Cintra do Amaral $^{25}$ e Vera Lúcia Machado D'Avila ${ }^{26}$ lecionam.

Passando do campo doutrinário para a postura das Cortes de Contas, convém trasladar abaixo a deliberação do Tribunal de Contas da União, a qual foi proferida na Decisão no 215/99:

Nas hipóteses de alterações contratuais consensuais, qualitativas e excepcionalíssimas de contratos de obras e serviços, é facultado à Administração ultrapassar os limites aludidos no item anterior, observados os princípios da finalidade, da razoabilidade e da proporcionalidade, além dos direitos patrimoniais do contratante privado, desde que satisfeito cumulativamente os seguintes pressupostos:

\footnotetext{
24 "Nota-se que a vedação contida no $\S 2^{\circ}$ do art. 65 da Lei n $8.666 / 93$ - a de exceder os 25\% ou 50\% está reportada tão-somente à alteração unilateral a que se remete a letra 'b' do inciso I ('quando necessária a modificação do valor contratual em decorrência de acréscimo ou diminuição quantitativa de seu objeto, nos limites permitidos por esta lei', os quais estão fixados no $\S 1^{\circ}$ ). Não diz respeito, pois, ao que está mencionado na letra 'a' ('modificação do projeto ou das especificações para melhor adequação técnicas aos seus objetivos')". (BANDEIRA DE MELLO, Celso Antônio. Curso de direito administrativo. 14. ed. São Paulo: Malheiros, 2002. p. 563).

25 "(...) a Administração costuma enfrentar na prática, evidencia que o limite legal de $25 \%$ (vinte e cinco por cento) para extensões contratuais, analisado à luz de sua 'ratio', constitui regra geral, que comporta exceções. A decisão de ultrapassar esse limite, em casos excepcionais - como é a modificação necessária ou indispensável do projeto -, contém-se na margem de discricionariedade do agente público, a quem cabe valorar os fatos e adotar a decisão que considere a mais compatível com o 'interesse público primário' a atender". (AMARAL, Antônio Carlos Cintra do. Ato administrativo, licitações e contratos administrativos. 1. ed. 2. tiragem. São Paulo: Malheiros, 1996. p. 132).

26 "(...) a possibilidade de alteração unilateral do contrato por parte da Administração é possível quando houver a necessidade de ser adequada a especificação técnica inicial do objeto contratado, limitando esse
} 
I - não acarretar para a Administração encargos contratuais superiores aos oriundos de uma eventual rescisão contratual por razões de interesse público, acrescidos aos custos da elaboração de um novo procedimento licitatório;

II - não possibilitar a inexecução contratual, à vista do nível de capacidade técnica e econômico-financeira do contratado;

III - decorrer de fatos supervenientes que impliquem em dificuldades não previstas ou imprevisíveis por ocasião da contratação inicial;

IV - não ocasionar a transfiguração do objeto originalmente contratado em outro de natureza e propósito diversos;

V - ser necessárias à completa execução do objeto original do contrato, À otimização do cronograma de execução e à antecipação dos benefícios sociais e econômico decorrentes;

VI - demonstrar-se na motivação do ato que autorizar o aditamento contratual que extrapole os limites legais mencionados na alínea "a", supra que as conseqüências de outra alternativa (a rescisão contratual, seguida de nova licitação e contratação) importam sacrifício insuportável ao interesse público primário (interesse coletivo) a ser atendido pela obra ou serviço, ou seja gravíssimas a esse interesse; inclusive quanto à sua urgência e emergência.

Noutra decisão, o mesmo Tribunal de Contas ratifica a sua colocação:

(...) tanto as alterações contratuais unilaterais quantitativas - que modificam a dimensão do objeto - quanto as unilaterais qualitativas - que mantém intangível o objeto, em natureza e em dimensão - estão sujeitas aos limites preestabelecidos nos $\S \S 1^{\circ}$ e $2^{\circ}$ do art. 65 da Lei 8.666/93, em face do respeito aos direitos do contratado, prescrito no art. 58, I, da mesma Lei, do princípio da proporcionalidade e da necessidade de esses limites serem obrigatoriamente fixados em lei; b) é permitido à Administração ultrapassar os aludidos limites, na hipótese de alterações contratuais consensuais, qualitativas e excepcionalíssimas, no sentido de que só seriam aceitáveis quando, no caso específico, a outra alternativa - a rescisão do contrato por interesse público, seguida de nova licitação e contratação - significar sacrifício insuportável ao interesse coletivo primário a ser atendido, pela obra ou serviço; ou seja, a revisão contratual qualitativa e consensual, que ultrapasse os limites preestabelecidos no art. $65, \S 1^{\circ}$, da Lei $8.666 / 93$, somente seria justificável, no caso concreto, quando as conseqüências da outra alternativa - a rescisão contratual, seguida de nova licitação e contratação - forem gravíssimas ao interesse público primário; (BRASIL. Tribunal de Contas da União. Decisão no 101/99. Relator: Min. José Antônio Barreto de Macedo).

poder à própria natureza do objeto, sem desnaturá-lo, transfigurá-lo ou aditá-lo a outro de natureza distinta.

Sendo assim, não são aplicáveis às alterações qualitativas do objeto contratado as limitações de quantidade previstas no $\$ 1^{\circ}$, do art. 65 da Lei n 8.666/93". (D’AVILA, Vera Lúcia Machado. Contrato. Alteração unilateral. Inexistência de limite quantitativo na hipótese do art. 65, inc. I, 'a'. In: DI PIETRO, Maria Sylvia; RAMOS, Dora Maria de Oliveira; SANTOS, Márcia Walquiria Batista dos; D'AVILA, Vera Lúcia Machado. Temas polêmicos sobre licitações e contratos. 3. ed. São Paulo: Malheiros, 1998. p. 258-259).

A \& C R. de Dir. Administrativo e Constitucional, Belo Horizonte, ano 6, n. 15, p. 109-132, jul./set. 2006 
Dessa forma, o Tribunal de Contas da União firma-se no sentido de que, em regra, as alterações qualitativas devem respeitar os percentuais do art. $65, \S 1^{\circ}$, da Lei $\mathrm{n}^{\mathrm{o}} 8.666 / 93$. Contudo, a regra comporta exceções, desde que o interesse público em determinada situação fática clame dessa maneira. Para tanto, a Administração deverá justificar e analisar o caso concreto com supedâneo nos princípios do regime jurídico do Direito Público, principalmente os da razoabilidade, da proporcionalidade, da economicidade e da finalidade pública.

\section{Conclusão}

Após as considerações supra expostas, conclui-se que o tema é bastante controvertido.

O Tribunal de Contas entende, a rigor, pela impossibilidade de que as alterações qualitativas excedam os limites percentuais fixados no $\S 1^{\circ}$ do art. 65 da Lei de Licitações. Admite somente em situações excepcionais a maleabilidade desta regra. Para tanto, o suporte fático deverá inclinar-se para o devido atendimento do interesse público primário clamado na contratação.

Doutro lado, ao meu ver, com o devido respeito às decisões do Tribunal de Contas da União e à parte da doutrina, compreendo que as alterações qualitativas não têm limites percentuais máximos. Não é impetuoso que a Administração Pública ao formalizar alteração qualitativa esteja vinculada à percentagem exposta no art. $65, \S 1^{\circ}$, da Lei de Licitações.

Isso porque, o referido percentual atina-se às alterações quantitativas e não qualitativas. Ademais, como o $\S 2^{\circ}$ do art. 65 refere-se ao $\S 1^{\circ}, \operatorname{logo}$ a afirmativa de que "nenhum acréscimo ou supressão poderá exceder os limites estabelecidos no parágrafo anterior" conduz a esta interpretação defendida. Outra intelecção desses preceptivos legais falece de respaldo normativo.

Em suma, a modificação do projeto ou das especificações do objeto (art. 65, inc. I, alínea “a”) padece de limites quantitativos. A conduta administrativa que efetue alterações qualitativas possui barreiras de acordo com o casuísmo e desde que não reste estereotipado burla ao dever de licitar ou afronta aos princípios do regime de Direito Público, sob pena de abuso de poder e, por via de conseqüência, desvio de finalidade pública.

\section{Referências}

ARAÚJO, Edmir Netto de. Contrato administrativo. São Paulo: R. dos Tribunais, 1987.

A \& C R. de Dir. Administrativo e Constitucional, Belo Horizonte, ano 6, n. 15, p. 109-132, jul./set. 2006 
BAZILLI, Roberto Ribeiro. Contratos administrativos. São Paulo: Malheiros, 1996.

BLANCHET, Luiz Alberto. Curso de direito administrativo. Curitiba: Juruá, 1998.

BRAZ, Petrônio. Processo de licitação. São Paulo: Livraria de Direito, 1995.

DALLARI, Adilson Abreu. Alterações dos contratos administrativos - economicidade, razoabilidade e eficiência. In: BACELLAR FILHO, Romeu Felipe (Coord.). Direito administrativo contemporâneo: estudos em memória do professor Manoel de Oliveira Franco. Belo Horizonte: Fórum, 2004.

GARCÍA DE ENTERRÍA, Eduardo; FERNÁNDEZ, Tomás-Ramón. Curso de direito administrativo. Trad. Arnaldo Setti. São Paulo: R. dos Tribunais, 1990.

MEDAUAR, Odete (Org.). Licitações Ė contratos administrativos: coletânea de estudos. São Paulo: NDJ, 1998.

MEIRELLES, Hely Lopes. Direito administrativo brasileiro. 23. ed. atual. São Paulo: Malheiros, 1990.

MELlo, Celso Antônio Bandeira de. Curso de direito administrativo. 14. ed. São Paulo: Malheiros, 2002.

PEREIRA JÚNIOR, Jessé Torres. Comentários à lei das licitações e contratações da Administração Pública. 6. ed. Rio de Janeiro: Renovar, 2003. p. 650.

SAMPAIO, Ricardo Alexandre. Revista Zênite de Licitações e Contratos - ILC, Curitiba, n. 130, p. 1162 , dez. 2004 .

SANTOS, Márcia Walquiria Batista dos. Contrato. Alteração unilateral. Princípio do contraditório. In: DI PIETRO, Maria Sylvia; RAMOS, Dora Maria de Oliveira; SANTOS, Márcia Walquiria Batista dos; D’AVILA, Vera Lúcia Machado. Temas polêmicos sobre licitações e contratos. 5. ed. São Paulo: Malheiros, 2001.

SOUTO, Marcos Jurena Villela. Direito administrativo contratual. Rio de Janeiro: Lumens Juris, 2004.

Informação bibliográfica deste texto, conforme a NBR 6023:2002 da Associação Brasileira de Normas Técnicas (ABNT):

REIS, Luciano Elias. Os limites das alterações qualitativas nos contratos administrativos. A\&C Revista de Direito Administrativo e Constitucional, Belo Horizonte, ano 6, n. 25, p. 109-132, jul./set. 2006 